\title{
Influence of Adding Mucilage as a Fat Replacer on the Characteristics of Yoghurt
}

Tammam, A.A.; M.A. Mohran; Manal M. Khodear and Abeer F. Zayan

${ }^{1}$ Dairy Department, Faculty of Agriculture, Assiut University, Assiut.

${ }^{2}$ Food Technology Research Institute, Agriculture Research Center.

Received on: $12 / 3 / 2019$

Accepted for publication on: 21/3/2019

\section{Abstract}

The objective of this study was to examine the effects of substituting milk fat with different levels of mucilage as a fat replacer on the chemical, microbiological and sensory characteristics of yoghurt. Raw cow milk was divided into two parts of whole fat milk and another part of skimmed milk with $0.0 \%, 0.01 \%$ and $0.025 \%$ and $0.05 \%$, respectively. The experimental yoghurt was compared with the control yoghurt produced from the whole milk and yoghurt control made from the skim milk without the addition of the mucilage. Samples of yoghurt were kept in a refrigerator at $\left(5 \pm 2 \mathrm{C}^{\circ}\right)$ for7 day. These samples were examined when fresh, and after 2,3 and $7^{\text {th }}$ the obtained results indicated that the addition of mucilage resulted in a significant increase in titratable acidity\%. The total solids content of yoghurt fortified with mucilage decrease gradually by increasing the concentration of added mucilage. Also, the total solids content of yoghurt in all of the treatments slightly increased during the storage period. On the other hand, less whey syneresis was observed during the storage of the yoghurt samples. On the other hand, replacing milk fat by mucilage was of no significant effect on fat content.

Addition of mucilage stimulated the growth of lactic acid bacteria. The colony forming units of total bacterial counts, Lactobacillus delbrueckii ssp. bulgaricus and Streptococcus thermophilus increased up to the 3rd day of the storage period, followed by a decrease up to the end of the storage period. Sensory evaluations were almost stable during the first $3^{\text {rd }}$ days of storage, then decreased slightly until the end of storage the period.

Yoghurt samples containing $0.01 \%$ of mucilage showed no different in the sensory characteristics compared with control and it the most acceptable sample. In conclusion, mucilage could be successfully used as a fat replacer in making of low fat yoghurt with additional nutritional benefits without affecting the physicochemical properties of yoghurt.

Keywords: Fat replacers, mucilage, quality of yoghurt.

\section{Introduction}

Yoghurt is among the most popular of dairy products due to various health claims and therapeutic values (Serafeimidou et al., 2012). In addition, yoghurt is a fermented dairy product with specific rheological and textural characteristics. Its texture results from the development of a three-dimensional network of milk proteins due to the aggregation of casein micelles with denatured whey proteins through hydrophobic and electrostatic bonds (Paseephol et al., 2008).

Current research tends to use fat replacers in the manufacture of dairy products. Fat replacers, which 
decrease the calorific value of food, can be used to solve some physical and organoleptic problems originating from low-fat levels in the final products. Fat replacers consist of mixtures of lipid originated fat substitutes, protein- or carbohydrate originated fat mimetics, or their combinations (Huyghebaert et al., 1996).

Okra is botanically known as Abelmoschus esculentus (L.) Moench, previously known as Hibiscus esculentus (L.), and belongs to the Malvaceae family. In 2010, its worldwide production was estimated close to 7 million metric tons (Dimopoulou et al., 2015). Okra is a perishable fruit and its skin is very susceptible to browning caused by the loss of water, thereby depressing its economic value for consumption in natural. The rejected fruit has a potential utilization due to the mucilaginous substances usually concentrated in the pod walls. Okra mucilage is a natural polysaccharide made up galactose, rhamnose, and galacturonic acid. It is a renewable and inexpensive source of biodegradable material. Its physical and chemical properties include high water solubility, plasticity, elasticity and viscosity (Monique et al., 2016).

Mucilage is a plant hydrocolloid, which is a polymer of a monosaccharide or mixed monosaccharide. In fact, polysaccharide mucilage is highly hydrophilic substances with high molecular weight molecules. The polysaccharides are soluble and dispersible in water due to their ability to interact with water and swell. The swelling properties are characterized by the entrapment of a large amount of water between the polymer chains and branches. Thus, mucilage can be used as one of the food additives, to modify the food quality in terms of food stability, texture and appearance properties by acting as emulsifiers, thickeners, and gelling agents or texture modifiers (Deogade et al., 2012).

The objective of this study was to investigate the possibility of using mucilage in the manufacture of lowfat yoghurt and study the effect of the addition of mucilage on chemical, microbiological and sensory properties of yoghurt during storage at refrigerator temperature.

\section{Materials and Methods Materials:}

Fresh cow's milk used in this study was obtained from the Collection Center, Arab El-awamer, Abnoub, Assiut. Okra was obtained from the local market in Assiut city. Lactobacillus delbrueckii ssp. bulgaricus LB340 and Streptococcus thermophilus were obtained from Dairy Enzymes Applications, Danisco, France. Metabisulphite and pure acetone were obtained from Sigma- Aldrich, UK.

\section{Methods:}

\section{Preparations and Manufacture Extraction of Okra mucilage:}

The okra was washed to remove any unnecessary dirt from their surfaces. The cleaned pods without seeds were then immediately frozen and kept at $-20^{\circ} \mathrm{C}$ to prevent any colour changes resulting from natural oxidation and browning process.

The extraction of okra mucilage was carried out according to the method done by Ameena et al. (2010) 
with some modifications. Initially, one $\mathrm{kg}$ of cleaned and sliced okra with different maturity indices was blended using $\sim 5^{\circ} \mathrm{C}$ distilled water containing $1 \% \quad(\mathrm{w} / \mathrm{v})$ of sodium metabisulphite. Then, the slurry was centrifuged at $3000 \mathrm{rpm}$ for 5 minutes and precipitated from the supernatant using pure acetone (99.5\%). The precipitated mucilage was washed several times with acetone and was freezing dried (Christ Alpha 1-4LD Plus, Germany). Then the freezedried okra mucilage was ground into powder form using a commercial dry blender.

\section{Yoghurt manufacture:}

All whole milk and the skim milk parts were heated to $90^{\circ} \mathrm{C}$ for 5 min. and then cooled immediately to $40 \pm 1^{\circ} \mathrm{C}$. The milk was inoculated at a rate of $2 \%$ with yoghurt starters then the general control (C1) made from whole fresh cow's and the three-skim milk were supplemented with Okra mucilage at different levels 0.01, 0.025 and $0.05 \%$, respectively. While the fourth parts were used as a control of skim milk yoghurt. Inoculated milk was dispensed in plastic cups of $100 \mathrm{ml}$ volume and incubated at the fermentation temperature $\left(40^{\circ} \mathrm{C}\right)$ until coagulation. Fermentation was stopped by rapid cooling to $5-6^{\circ} \mathrm{C}$. Yoghurt samples were analyzed when fresh, 2, 3 and 7 days of storage (Tamime and Robinson, 1999). All experiments were carried out in triplicate.

\section{Chemical analyses:}

Titratable acidity and total solids of the experimental samples were determined according to A.O.A.C. (2000). Percentage of fat content and moisture had been determined according to Ling (1963). Percentage of the total nitrogen (T.N) content and soluble nitrogen (S.N) content was determined by using the Kjeldahl method according to A.O.A.C. (2000).

\section{Rheological properties:}

Syneresis was determined by measuring the volume of separated whey ( $\mathrm{ml}$ whey $/ 50 \mathrm{ml}$ yoghurt) collected after $30 \mathrm{~min}$ at room temperature (Abd-EL-Salam et al., 1991).

\section{Microbiological analysis:}

Total bacterial count (T.B.C.) in the samples was determined by using the standard plate count technique. Appropriate dilutions of yoghurt samples were plated in duplicate on an agar medium (FIL/IDF, 1991). Lactic acid bacteria (L.A.B.) in the samples were according to the International Standard FIL/IDF 117A (1988). Determination of coliform bacteria had been carried out according to the International Standard FIL/IDF 65 (1971). Counts of yeasts and moulds had been carried out according to the International Standard FIL/IDF 67 (1971).

\section{Organoleptic properties:}

Yoghurt samples were assessed according to Abou- Donia et al. (1991) when fresh and after 2, 3 and 7 days of storage by ten panellists of staff members at Department of Dairy Science, Food Technology Research Institute.

\section{Statistical analyses:}

The obtained data were subjected to statistical analysis, using "F-test". Means were compared using the least significant difference (L.S.D. test). Data were performed in 
the computer using the SPSS package

\section{Results and Discussion}

\section{Chemical analyses:}

The data in Table (1) show that developed titratable acidity (TA \%) of yoghurt treatments increased significantly $(p \leq 0.05)$ as the storage period increased.

Replacement of milk fat with Mucilage caused a significant increase in TA\% (Table 1). These results might be due to the higher water holding capacity of Mucilage. Also, it has been claimed that Mucilage stimulates the growth of lactic acid bacteria. These results are in agreement with those of Nikoofar et al. (2013). Also, it could be observed in Table (1), that yoghurt made from whole milk $\left(\mathrm{C}_{1}\right)$ had significantly $(p \leq 0.05)$ higher total solids (TS) when fresh and during storage, compared with other yoghurt treatments.

Whereas the lowest TS content was observed in yoghurt, samples made from skim milk $\left(\mathrm{C}_{2}\right)$. Also, the TS content of yoghurt in all treatments slightly increased with the progress of the storage period. TS content of yoghurt fortified with mucilage decrease gradually by increasing the percentage of added
(SPSS, 1998).

Mucilage $(p \leq 0.05)$. These results might be due to the higher water holding capacity of Mucilage. These results are in agreement with those of Tamime and Robinson (1999).

Results also showed slight changes were observed in the total protein and soluble nitrogen of yoghurts from different treatments during storage. Where found that the total protein and soluble nitrogen contents decreased by increasing Mucilage levels. On the other hand, The total protein and soluble nitrogen contents increased in all treatments as the storage period progressed. These results are in agreement with those of Abd EL-Salam et al. (1996), Kebary and Hussein (1999), Tamime and Robinson (1999) and Kebary et al. (2004).

The obtained results also showed that the fortification of low-fat yoghurt with Mucilage as fat replacers did not affect the fat content of the yoghurt. These results are in agreement with those reported by Kebary et al. (1996), Kebary and Hussein (1999), Hussein et al. (2004) and Badawi et al. (2008). 
Table 1. Changes in the chemical composition of yoghurt as affected by the addition of Mucilage through the storage at 5- $7^{\circ} \mathrm{C}$ for $7^{\text {th }}$ days

\begin{tabular}{|c|c|c|c|c|c|}
\hline \multirow{2}{*}{ Components (\%) } & \multirow{2}{*}{ Treatments } & \multicolumn{4}{|c|}{ Storage Period (Days) } \\
\hline & & $\mathbf{0}$ & 2 & 3 & 7 \\
\hline \multirow{7}{*}{$\begin{array}{l}\text { Titratable } \\
\text { acidity }\end{array}$} & $C_{1}$ & $0.97^{\mathrm{A}}$ & $1.04^{\mathrm{B}}$ & $1.07^{\mathrm{BC}}$ & $1.12^{\mathrm{CD}}$ \\
\hline & $\mathrm{C}_{2}$ & $0.92^{\mathrm{B}}$ & $1.00^{C}$ & $1.04^{\mathrm{C}}$ & $1.09^{\mathrm{D}}$ \\
\hline & $\mathbf{T}_{1}$ & $0.98^{\mathrm{A}}$ & $1.07^{\mathrm{B}}$ & $1.09^{\mathrm{B}}$ & $1.13^{C}$ \\
\hline & $\mathbf{T}_{2}$ & $0.99^{\mathrm{A}}$ & $1.11^{\mathrm{A}}$ & $1.15^{\mathrm{A}}$ & $1.25^{\mathrm{B}}$ \\
\hline & $\mathbf{T}_{3}$ & $0.99^{\mathrm{A}}$ & $1.11^{\mathrm{A}}$ & $1.18^{\mathrm{A}}$ & $1.31^{\mathrm{A}}$ \\
\hline & F-Test & $* *$ & $* *$ & $* *$ & $* *$ \\
\hline & $\mathbf{L S D}_{0.05}$ & 0.037 & 0.036 & 0.036 & 0.036 \\
\hline \multirow[t]{7}{*}{ Total Solids } & $\mathrm{C}_{1}$ & $12.27^{\mathrm{A}}$ & $12.38^{\mathrm{A}}$ & $12.43^{\mathrm{A}}$ & $12.50^{\mathrm{A}}$ \\
\hline & $\mathrm{C}_{2}$ & $10.47^{\mathrm{E}}$ & $10.50^{\mathrm{E}}$ & $10.53^{\mathrm{E}}$ & $10.88^{\mathrm{C}}$ \\
\hline & $\mathbf{T}_{1}$ & $11.42^{\mathrm{B}}$ & $11.59^{\mathrm{B}}$ & $11.68^{\mathrm{B}}$ & $12.50^{\mathrm{A}}$ \\
\hline & $\mathbf{T}_{2}$ & $11.38^{\mathrm{C}}$ & $11.45^{\mathrm{C}}$ & $11.57^{\mathrm{C}}$ & $12.47^{\mathrm{A}}$ \\
\hline & $\mathbf{T}_{3}$ & $11.26^{\mathrm{D}}$ & $11.35^{\mathrm{D}}$ & $11.40^{\mathrm{D}}$ & $12.22^{\mathrm{B}}$ \\
\hline & F-Test & $* *$ & $* *$ & $* *$ & $* *$ \\
\hline & $\mathbf{L S D}_{0.05}$ & 0.036 & 0.036 & 0.037 & 0.037 \\
\hline \multirow[t]{7}{*}{ Total protein } & $\mathrm{C}_{1}$ & $2.43^{\mathrm{D}}$ & $2.55^{\mathrm{D}}$ & $2.92^{\mathrm{C}}$ & $3.09^{\mathrm{B}}$ \\
\hline & $\mathrm{C}_{2}$ & $2.79^{\mathrm{B}}$ & $2.79^{C}$ & $3.26^{\mathrm{A}}$ & $3.29^{\mathrm{A}}$ \\
\hline & $T_{1}$ & $2.97^{\mathrm{A}}$ & $2.98^{\mathrm{A}}$ & $3.04^{\mathrm{B}}$ & $3.0^{\mathrm{B}}$ \\
\hline & $T_{2}$ & $2.79^{\mathrm{B}}$ & $2.88^{\mathrm{B}}$ & $3.03^{\mathrm{B}}$ & $3.06^{\mathrm{BC}}$ \\
\hline & $\mathbf{T}_{3}$ & $2.54^{\mathrm{C}}$ & $2.54^{\mathrm{D}}$ & $3.01^{\mathrm{B}}$ & $3.04^{\mathrm{C}}$ \\
\hline & F-Test & $* *$ & $* *$ & $* *$ & $* *$ \\
\hline & $\mathbf{L S D}_{0.05}$ & 0.039 & 0.036 & 0.036 & 0.036 \\
\hline \multirow{7}{*}{$\begin{array}{c}\text { Water soluble } \\
\text { nitrogen }\end{array}$} & $\mathrm{C}_{1}$ & $0.045^{\mathrm{D}}$ & $0.105^{\mathrm{C}}$ & $0.126^{C}$ & $0.213^{\mathrm{B}}$ \\
\hline & $\mathrm{C}_{2}$ & $0.052^{\mathrm{C}}$ & $0.182^{\mathrm{A}}$ & $0.210^{\mathrm{A}}$ & $0.252^{\mathrm{A}}$ \\
\hline & $T_{1}$ & $0.098^{\mathrm{A}}$ & $0.112^{B}$ & $0.154^{\mathrm{B}}$ & $0.213^{\mathrm{B}}$ \\
\hline & $T_{2}$ & $0.098^{\mathrm{A}}$ & $0.112^{\mathrm{B}}$ & $0.125^{C}$ & $0.203^{C}$ \\
\hline & $\mathbf{T}_{3}$ & $0.063^{\mathrm{B}}$ & $0.098^{\mathrm{D}}$ & $0.112^{D}$ & $0.126^{\mathrm{D}}$ \\
\hline & F-Test & $* *$ & $* *$ & $* *$ & $* *$ \\
\hline & $\mathbf{L S D}_{0.05}$ & 0.036 & 0.036 & 0.036 & 0.036 \\
\hline \multirow[t]{7}{*}{ Fat } & $\mathrm{C}_{1}$ & $2.5^{\mathrm{A}}$ & $2.5^{\mathrm{A}}$ & $2.7^{\mathrm{A}}$ & $3.1^{\mathrm{A}}$ \\
\hline & $\mathrm{C}_{2}$ & $0.7^{\mathrm{B}}$ & $0.7^{\mathrm{B}}$ & $0.8^{\mathrm{B}}$ & $1.1^{\mathrm{B}}$ \\
\hline & $T_{1}$ & $0.7^{\mathrm{B}}$ & $0.7^{\mathrm{B}}$ & $0.8^{\mathrm{B}}$ & $1.1^{\mathrm{B}}$ \\
\hline & $T_{2}$ & $0.6^{\mathrm{B}}$ & $0.6^{\mathrm{B}}$ & $0.6^{\mathrm{B}}$ & $0.8^{\mathrm{B}}$ \\
\hline & $\mathbf{T}_{3}$ & $0.6^{\mathrm{B}}$ & $0.6^{\mathrm{B}}$ & $0.7^{\mathrm{B}}$ & $0.7^{\mathrm{B}}$ \\
\hline & F-Test & $* *$ & $* *$ & $* *$ & $* *$ \\
\hline & $\mathbf{L S D}_{0.05}$ & 0.48 & 0.48 & 0.41 & 0.29 \\
\hline
\end{tabular}

Each value in the Table was the mean of three replicates.

A, B, C and D: Means having different superscripts within each column are significantly different $(\mathrm{P} \leq 0.05)$.

$\mathrm{C}_{1}$ : Control yoghurt made from whole cow milk.

$\mathrm{C}_{2}$ : Control yoghurt made from cow skim milk without the addition of Mucilage.

$\mathrm{T}_{1}$ : Yoghurt made from cow skim milk $+0.01 \%$ Mucilage.

$\mathrm{T}_{2}$ : Yoghurt made from cow skim milk $+0.025 \%$ Mucilage.

$\mathrm{T}_{3}$ : Yoghurt made from cow skim milk $+0.05 \%$ Mucilage. 
Rheological properties:

\section{Syneresis:}

The syneresis of yoghurt was affected by the concentration of added Mucilage used as shown in Table (2). Replacement of milk fat with Mucilage caused a significant $(\mathrm{p} \leq 0.05)$ reduction of whey syneresis from curd and this reduction was proportional to the rate of replacement. Similar results were reported by Farooq and Haque (1992), Kebary and Hussein (1999) and Nikoofar et al., (2013).

These results might be due to the addition of Mucilage leads to form a complex with casein micelles and prevent them from excessive fusion and from a fine meshed gel network, which is less susceptible to whey separation and/or increasing the water holding capacity (Danneberg and Kessler, 1988). Syneresis from all yoghurt treatments decreased gradually $(\mathrm{p} \leq 0.05)$ as the storage period progressed and reached their minimum values on the seventh day of storage period. These results are in agreement with those reported by Farooq and Haque (1992), Kebary and Hussein (1999) and Kebary et al. (2009).

\section{Microbiological characteristics:}

Data presented in Table (3) illustrated that the total bacterial count and lactic acid bacteria followed similar results. Total bacteria and lactic acid bacteria counts increased as the storage period progressed up to the third day, and then decreased up to the end of the storage period. These results might be due to the development of acidity. These results are in harmony with those finding of Kebary et al. (1996), Kebary and Hussein (1999), Kebary et al. (2004), Kebary et al. (2007), Badawi et al. (2008), Naji et al. (2012) and Mohamed et al. (2013) and EL-Sonbaty et al. (2008). The obtained results also showed that the count of lactic acid bacteria of all treatments with Mucilage had a higher count than the control at any time.

Table 2. Changes of syneresis in yoghurt as affected by the addition of mucilage through the storage at 5- $7^{\circ} \mathrm{C}$.

\begin{tabular}{|c|c|c|c|c|}
\hline \multirow{2}{*}{ Treatments } & \multicolumn{4}{|c|}{ Storage Period (Days) } \\
\cline { 2 - 5 } & $\mathbf{0}$ & $\mathbf{2}$ & $\mathbf{3}$ & $\mathbf{7}$ \\
\hline $\mathbf{C}_{\mathbf{1}}$ & $29^{\mathrm{BC}}$ & $27^{\mathrm{BC}}$ & 26 & 25 \\
\hline $\mathbf{C}_{\mathbf{2}}$ & $33^{\mathrm{A}}$ & $32^{\mathrm{A}}$ & 30 & 27 \\
\hline $\mathbf{T}_{\mathbf{1}}$ & $32^{\mathrm{AB}}$ & $31^{\mathrm{AB}}$ & 28 & 27 \\
\hline $\mathbf{T}_{\mathbf{2}}$ & $30^{\mathrm{AB}}$ & $29^{\mathrm{ABC}}$ & 27 & 26 \\
\hline $\mathbf{T}_{\mathbf{3}}$ & $26^{\mathrm{C}}$ & $26^{\mathrm{C}}$ & 25 & 24 \\
\hline F-Test & $*$ & $*$ & N.S & N.S \\
\hline LSD $_{\mathbf{0 . 0 5}}$ & 3.638 & 3.844 & - & - \\
\hline
\end{tabular}

Each value in the Table was the mean of three replicates.

A,B,C and D: Means having different superscripts within each column are significantly different $(\mathrm{P} \leq 0.05)$.

$\mathrm{C}_{1}$ : Control yoghurt made from whole cow milk.

$\mathrm{C}_{2}$ : Control yoghurt made from cow skim milk without the addition of Mucilage.

$\mathrm{T}_{1}$ : Yoghurt made from cow skim milk $+0.01 \%$ Mucilage.

$\mathrm{T}_{2}$ : Yoghurt made from cow skim milk $+0.025 \%$ Mucilage.

$\mathrm{T}_{3}$ : Yoghurt made from cow skim milk $+0.05 \%$ Mucilage. 
The count of total bacterial counts and lactic acid bacteria increased by increasing the rate of adding mucilage. These results might be due to the stimulation effect of mucilage on the growth of microflora (Gibson and Roberfroid, 1995, Kebary et al., 2005, Donkor et al., 2007 and Oliveira et al., 2009). Also, results showed that all samples were free of the count of yeast and moulds and coliform bacteria during the storage period.

These results were disagreement with what was found by Mohamed (2004), who found that yeasts and moulds free during storage at $5^{\circ} \mathrm{C}$ or $25^{\circ} \mathrm{C}$. While moulds and yeasts were not detected in yoghurt containing cress seeds in fresh and through the storage period.

Table 3. Changes in microbiological characteristics yoghurt manufactured by a mucilage through the storage at $5-7^{\circ} \mathrm{C}$. (Cfu/gm).

\begin{tabular}{|c|c|c|c|c|c|}
\hline \multirow{2}{*}{ Determination } & \multirow[t]{2}{*}{ Treatments } & \multicolumn{4}{|c|}{ Storage Period /Days } \\
\hline & & $\mathbf{0}$ & 2 & 3 & 7 \\
\hline \multirow{7}{*}{$\begin{array}{l}\text { Total plate } \\
\text { count }\end{array}$} & $\mathrm{C}_{1}$ & $16.9 \times 10^{6 \mathrm{E}}$ & $24.65 \times 10^{6 \mathrm{D}}$ & $26.15 \times 10^{6 \mathrm{D}}$ & $15.9 \times 10^{6 \mathrm{E}}$ \\
\hline & $\mathrm{C}_{2}$ & $22.95 \times 10^{6 \mathrm{D}}$ & $24.95 \times 10^{6 \mathrm{D}}$ & $27.4 \times 10^{6 \mathrm{D}}$ & $18.55 \times 10^{6 \mathrm{D}}$ \\
\hline & $T_{1}$ & $84.55 \times 10^{6 \mathrm{~A}}$ & $91.5 \times 10^{7 \mathrm{~A}}$ & $97.0 \times 10^{7 \mathrm{~A}}$ & $86.5 \times 10^{6 \mathrm{~A}}$ \\
\hline & $T_{2}$ & $56.05 \times 10^{6 \mathrm{~B}}$ & $58.2 \times 10^{7 \mathrm{~B}}$ & $65.55 \times 10^{7 \mathrm{~B}}$ & $52.75 \times 10^{6 \mathrm{~B}}$ \\
\hline & $T_{3}$ & $45.40 \times 10^{6 \mathrm{C}}$ & $48.50 \times 10^{7 \mathrm{C}}$ & $53.0 \times 10^{7 \mathrm{C}}$ & $42.35 \times 10^{6 \mathrm{C}}$ \\
\hline & F-Test & $* *$ & $* *$ & $* *$ & $* *$ \\
\hline & $\mathbf{L S D}_{0.05}$ & 0.045 & 0.042 & 0.041 & 0.045 \\
\hline \multirow{7}{*}{$\begin{array}{c}\text { Lactic acid } \\
\text { bacteria }\end{array}$} & $\mathrm{C}_{1}$ & $40.5 \times 10^{5 \mathrm{D}}$ & $66.0 \times 10^{5 \mathrm{C}}$ & $84.5 \times 10^{5 \mathrm{~B}}$ & $41.7 \times 10^{5 \mathrm{C}}$ \\
\hline & $\mathrm{C}_{2}$ & $13.9 \times 10^{6 \mathrm{~A}}$ & $15 \times 10^{6 \mathrm{~A}}$ & $15.85 \times 10^{6 \mathrm{~A}}$ & $11.55 \times 10^{5 \mathrm{D}}$ \\
\hline & $\mathbf{T}_{1}$ & $51.5 \times 10^{5 \mathrm{C}}$ & $62.5 \times 10^{6 \mathrm{CD}}$ & $63.0 \times 10^{6 \mathrm{C}}$ & $52.0 \times 10^{5 \mathrm{~A}}$ \\
\hline & $\mathbf{T}_{2}$ & $50.0 \times 10^{5 \mathrm{C}}$ & $59.0 \times 10^{6 \mathrm{D}}$ & $62.0 \times 10^{6 \mathrm{C}}$ & $50.85 \times 10^{5 \mathrm{~A}}$ \\
\hline & $\mathbf{T}_{3}$ & $74.4 \times 10^{5 \mathrm{~B}}$ & $81.0 \times 10^{6 \mathrm{~B}}$ & $87.0 \times 10^{6 \mathrm{~B}}$ & $46.2 \times 10^{5 \mathrm{~B}}$ \\
\hline & F-Test & $* *$ & $* *$ & $* *$ & $* *$ \\
\hline & LSD $_{0.05}$ & 0.041 & 0.041 & 0.043 & 0.037 \\
\hline \multirow{7}{*}{$\begin{array}{l}\text { Yeast and } \\
\text { moulds }\end{array}$} & $\mathrm{C}_{1}$ & Nil & Nil & Nil & Nil \\
\hline & $\mathrm{C}_{2}$ & Nil & $\mathrm{Nil}$ & Nil & Nil \\
\hline & $T_{1}$ & Nil & Nil & Nil & Nil \\
\hline & $\mathbf{T}_{2}$ & Nil & Nil & Nil & Nil \\
\hline & $T_{3}$ & Nil & Nil & Nil & Nil \\
\hline & F-Test & - & - & - & - \\
\hline & $\mathbf{L S D}_{0.05}$ & - & - & - & - \\
\hline \multirow{7}{*}{$\begin{array}{l}\text { Coliform } \\
\text { bacteria }\end{array}$} & $\mathrm{C}_{1}$ & Nil & Nil & Nil & Nil \\
\hline & $\mathrm{C}_{2}$ & Nil & Nil & Nil & Nil \\
\hline & $T_{1}$ & Nil & Nil & Nil & Nil \\
\hline & $\mathbf{T}_{2}$ & Nil & Nil & Nil & Nil \\
\hline & $\mathbf{T}_{3}$ & Nil & Nil & Nil & Nil \\
\hline & F-Test & - & - & $=$ & - \\
\hline & $\mathbf{L S D}_{0.05}$ & - & - & - & - \\
\hline
\end{tabular}

Each value in the Table was the mean of three replicates.

$\mathrm{A}, \mathrm{B}, \mathrm{C}$ and $\mathrm{D}$ : Means having different superscripts within each column are significantly different $(\mathrm{P} \leq 0.05)$.

$\mathrm{C}_{1}$ : Control yoghurt made from whole cow milk.

$\mathrm{C}_{2}$ : Control yoghurt made from cow skim milk without the addition of Mucilage.

$\mathrm{T}_{1}$ : Yoghurt made from cow skim milk $+0.01 \%$ Mucilage.

$\mathrm{T}_{2}$ : Yoghurt made from cow skim milk $+0.025 \%$ Mucilage.

$\mathrm{T}_{3}$ : Yoghurt made from cow skim milk $+0.05 \%$ Mucilage. 
This is due to the presence of cress seeds, which contain several compounds as possess antimicrobial against food spoilage organisms. Behrouzian et al. (2014) found that coliform and aerobic spore-forming bacteria were not detected in all yoghurt treatments either when fresh or during the storage period. This may be due to the high hygienic condition during the preparation.

\section{Organoleptic properties:}

Scores of organoleptic properties (flavour, body \& texture, appearance, acidity and total scores) followed almost similar trends (Table 4). Yoghurt made from skim milk without adding Mucilage $\left(\mathrm{C}_{2}\right)$ gained the lowest scores for organoleptic properties and was different from other yoghurt treatments. Fortification of skim milk with Mucilage improved the organoleptic properties of yoghurt. Treatment that made from skim milk fortified with $0.01 \%$ was not different from yoghurt that made from whole milk $\left(\mathrm{C}_{1}\right)$. Storage up to the $3^{\text {rd }}$ day did not affect the scores of organoleptic properties, then scores of all yoghurt treatments decreased gradually up to the end of the storage period. These results are in agreement with those reported by Kebary and Hussein (1999) and Kebary et al. (2004).

Table 4. Effect of mucilage ratios on organoleptic properties of low-fat yoghurt during storage period at $5-7^{\circ} \mathrm{C}$.

\begin{tabular}{|c|c|c|c|c|c|c|}
\hline \multirow{4}{*}{ Treatment } & $\begin{array}{c}\text { Storage } \\
\text { period } \\
\text { (days) }\end{array}$ & $\begin{array}{c}\text { Flavor } \\
\mathbf{( 4 5 )}\end{array}$ & $\begin{array}{c}\text { Body\& } \\
\text { texture } \\
\mathbf{( 3 0 )}\end{array}$ & $\begin{array}{c}\text { Appearance } \\
\mathbf{( 1 5 )}\end{array}$ & $\begin{array}{c}\text { Acidity } \\
\mathbf{( 1 0 )}\end{array}$ & $\begin{array}{c}\text { Total } \\
\mathbf{( 1 0 0 )}\end{array}$ \\
\hline \multirow{4}{*}{ C1 } & 0 & 38.50 & 25.00 & 12.88 & 8.69 & 85.07 \\
\cline { 2 - 7 } & 2 & 37.55 & 27.23 & 12.91 & 7.77 & 85.46 \\
\cline { 2 - 7 } & 3 & 36.83 & 27.83 & 12.00 & 7.83 & 84.49 \\
\cline { 2 - 7 } & 7 & 30.63 & 21.13 & 9.50 & 8.13 & 69.39 \\
\hline \multirow{4}{*}{ C2 } & 0 & 34.33 & 23.33 & 10.33 & 4.67 & 72.67 \\
\cline { 2 - 7 } & 2 & 35.67 & 21.33 & 9.67 & 6.33 & 73.00 \\
\cline { 2 - 7 } & 3 & 39.50 & 26.83 & 12.67 & 7.50 & 88.67 \\
\cline { 2 - 7 } & 7 & 39.33 & 25.67 & 12.67 & 9.00 & 86.67 \\
\hline \multirow{4}{*}{ T1 } & 0 & 36.67 & 26.67 & 11.33 & 6.67 & 81.33 \\
\cline { 2 - 7 } & 2 & 41.67 & 26.00 & 13.67 & 8.33 & 89.33 \\
\cline { 2 - 7 } & 3 & 37.67 & 25.33 & 12.67 & 8.00 & 83.67 \\
\cline { 2 - 7 } & 7 & 31.33 & 23.33 & 10.33 & 6.67 & 71.67 \\
\hline \multirow{4}{*}{ T2 } & 0 & 35.00 & 20.00 & 6.67 & 6.00 & 67.67 \\
\cline { 2 - 7 } & 2 & 37.00 & 23.33 & 11.33 & 6.33 & 78.00 \\
\cline { 2 - 7 } & 3 & 39.50 & 26.83 & 12.67 & 7.50 & 88.67 \\
\cline { 2 - 7 } & 7 & 38.00 & 25.33 & 12.67 & 8.67 & 84.67 \\
\hline \multirow{4}{*}{ T3 } & 0 & 37.67 & 23.33 & 9.33 & 7.33 & 77.67 \\
\cline { 2 - 7 } & 2 & 41.00 & 27.33 & 13.50 & 8.33 & 95.00 \\
\cline { 2 - 7 } & 3 & 40.67 & 25.33 & 12.67 & 8.00 & 86.67 \\
\cline { 2 - 7 } & 7 & 39.33 & 25.67 & 11.67 & 8.67 & 85.33 \\
\hline
\end{tabular}




\section{References}

A.O.A.C. (2000). Association of Official Analytical Chemists. Official Methods of Analysis Association of Official Agriculture Chemists. $17^{\text {th }}$ ed. Wisconsin: Georgia Banta Co. Inc.

Abd El-Salam, M.H., H.M., EL-Etriby and N.M., Shahein (1996). Influence of some stabilizers on some chemical and physical properties of yoghurt. Egyptian J. Dairy Sci. 24: 25-36.

Abd-EL-Salam, M.H., S., EL-Shibiniy, M.B., Mahfuz, H.F., EL-Dein, H., EL-Atriby and V., Antila (1991). Preparation of whey protein concentrate from salted whey and its use in yoghurt. J. Dairy Rese.58: 503.

Abou-Donia, S.A., I.A., Attia, A.A., Khattab and Z., EL-Shenawi (1991). Formulation of dried cereal fermented milk with prolonged storage life. Egyptian J. Dairy Sci. 19: 283-299.

Ameena, K., C., Dilip, R., Saraswathi, P.N., Krishnan, C., Sankar and S.P., Simi (2010). Isolation of the mucilages from Hibiscus rosasinensis linn and Okra (Abelmoschus esculentus linn) and studies of the binding effects of the mucilages. Asian Pacific J. Tropical Medicine. 3 (7): 539-543.

Badawi, R.M., A.I., Hamed, K.M.K., Kebary and H.A., EL-Sayed (2008). Effect of replacing milk fat with fat replacers on the quality of stirred yoghurt. Egyptian J. Dairy Sci. 36 (2): 197-206.

Behrouzian, F., S.M.A., Razavi and G.O., Phillips (2014). Cress seed (Lepidium sativum) mucilage: An overview. Bioact Carbohydr Dietary Fiber 3: 17-28.

Danneberg, F. and H.G., Kessler (1988). Effect of denaturation of $\beta$ - lactoglobulin on texture properties of set- type non- fat yoghurt. I. Synersis. Milchwissenschaft 43: 632-635.

Deogade, U.M., V.N., Deshmukh and D.M., Sakarkar (2012). Natural gums and gum's in NDDS: Applications and recent approaches. Inte. J. Pharm. Tech. Res. 4 (2): 799-814.

Dimopoulou, M., C., Ritzoulis, C., Panayiotou and P. Costas (2015). Surface characterization of okra hydrocolloid extract by inverse gas chromatography (IGC). Colloids and Surfaces A: Physicochemical and Engineering Aspects.475: 3743

Donkor, O.N., S.L.I., Nilmini, P., Stolic, T., Vasiljevic and N.P., Shah (2007). Survival and activity of selected probiotic organisms in set -type during cold storage. Intr. Dairy J. 17 (6): 657-665.

EL-Sonbaty, A.H., K.M.K., Kebary, R.M., Badawi and H.A., EL-Sayed (2008). Effect of stabilizers on the quality of stirred yoghurt. Egyptian J. Dairy Sci. 36 (2): 185-195.

Farooq, K. and Z.U., Haque (1992). Effect of sugar esters on the textural properties of non-fat lowcalorie yoghurt. J. Dairy Sci. 75: 2676-2680.

FIL/IDF Standard (117A/1988). Yoghurt: Enumeration of Characteristic MicroorganismsColony Count Technique at $37 \mathrm{C}^{\circ}$. International Dairy Federation, 41square Vergote, 1040 Brussels, Belgium.

FIL/IDF Standard (153/1991). Butter, fermented milks and fresh cheese. Enumeration of contaminating microorganisms. Colony count technique at $30^{\circ} \mathrm{C}$. International Dairy Federation Standard 153. 
FIL/IDF Standard (65/1971). Fermented Milks: Count of Coliforms (reference method). International Dairy Federation, 41square Vergote, 1040 Brussels, Belgium.

FIL/IDF Standard (67/1971). Fermented Milks: Count of Yeasts \& moulds (reference method). International Dairy Federation, 41square Vergote, 1040 Brussels, Belgium.

Gibson, G.R. and M.B., Roberfroid (1995). Dietary modulation of the human colonic microbiota: Introducing the concept of perbiotics. J. Nut. 125: 1401-1412.

Hussein, S.A., R.M., Badawi and I.I., Badran (2004). Quality of fat free yoghurt made with fat replacer. Minufiya J. Agric. Res. 29 (6): 1295-1315.

Huyghebaert, A., K., Dewettinck and W., de Greyt (1996). Fat replacers. In Fat Replacers-Ripening and Quality of Cheese. IDF Bulletin 317: 1996, pp 10-15. Brussels: International Dairy Federation.

Kebary, K.M.K. and S.A., Hussein (1999). Manufacture of low fat zabady using different fat replacers. Acta Alimetaria 28(1): $1-14$.

Kebary, K.M.K., R.M., Badawi, I.I., Badran and S.A., Hussein (2005). Influence of some nutrients and bile salt on the production of antimicrobial agents by bifidobacteria. Egyptian J. Dairy Sci. 33: 157-170.

Kebary, K.M.K., S.A., Hussein and R.M., Badawi (2004). Impact of fortification of cow's milk with a modified starch on yoghurt quality. Egyptian J. Dairy Sci. 32 (1): 111 124.

Kebary, K.M.K., S.A., Hussein, R.M., Badawi and I.I., Badran (2007). Incorporation of bifidobacteria in low fat Labneh. Proc. $10^{\text {th }}$
Egyptian Conf. Dairy Sci. and Technol. pp. 359-375.

Kebary, K.M.K., A.M., Moussa, A.I., Hamed and E.T., Yousef (1996). Quality of zabady made with Bifidobacterium bifidum DI. The proceeding of 36th Science Week, Supreme Council of Science, Alepo University, Syria, Book 3, part 1: 79-91.

Ling, E.R. (1963). A text book of dairy chemistry, $3^{\text {rd }}$ ed. Chapman and Hall, Ltd., London.

Mohamed, A.G. (2004). Studies on spreadable processed cheese emulsifying salts. Ph.D. Thesis Faculty Agric., Cairo University, Cairo, Egypt.

Mohamed, A.G., B.E., Abo-El-Khair and S.M., Shalaby (2013). Quality of novel healthy processed cheese analogue enhanced with marine microalgae chlorella vulgaris biomass. World Appl. Sci. J. 23 (7): 914-925.

Monique, A.P.C., C.M., Artur and A., Eliane (2016). Preparation and characterization of Okra Mucilage (Abelmoschus esculentus) Edible Films. Macromol. Symp. 367: 90100.

Naji, S., S.M.A., Razavi, and H., Karazhiyan (2012). Effect of thermal treatments on functional properties of cress seed (Lepidium sativum) and xanthan gums: A comparative study. Food Hydrocolloids; 28: 75-81.

Nikoofar, E., M., Hojjatoleslami and M.A., Shariaty (2013). Surveying the effect of quince seed mucilage as a fat replacer on texture and physicochemical properties of semi fat set yoghurt. Int. J. Farm Alli. Sci. 2: 861-865.

Oliveira, R.P.D.; P., Perego, A., Converti and M.N., Deoliveira (2009). Effect of inulin on growth and acidification performance of 
different probiotic bacteria in cocultures and mixed cultures in: The streptococcus thermophilus. J. Food Enginee. 91: 133-139.

Paseephol T., D.M., Small and F., Sherkat (2008). Rheology and texture of set yogurt as affected by inulin addition. Journal of Texture Studies 39, 617-634.

Serafeimidou A., S., Zlatanos, L., Kostas and A., Sagredos (2012). Chemical characteristics, fatty acid composition and conjugated linoleic acid (CLA) content of traditional Greek yoghurts. Food Chemistry 134, 1839-1846.

SPSS. (1998). SPSS for Windows. Release 9.0.0. SPSS Inc.

Tamime, A.Y. and R.K. Robinson (1999). Yoghurt Science and Technology, $1^{\text {st }}$ Edn., Woodhead Publishing Ltd., London. 


\section{تأثثير الميوسيلاج كبديل للاهن على خصائص الزبادي

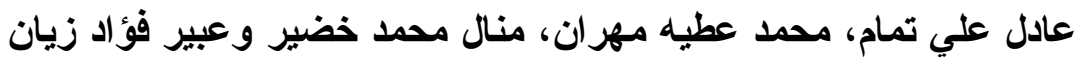

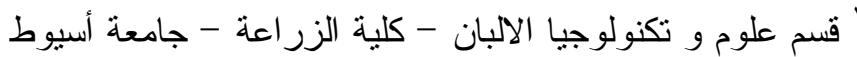

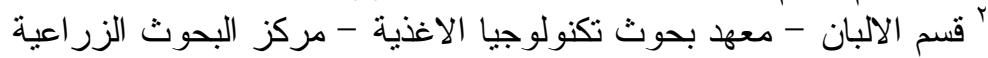

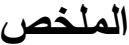

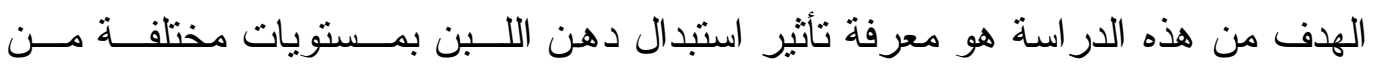

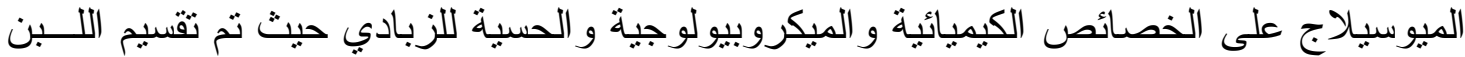

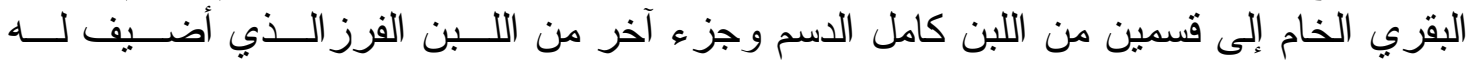

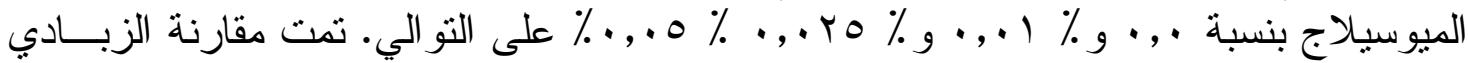

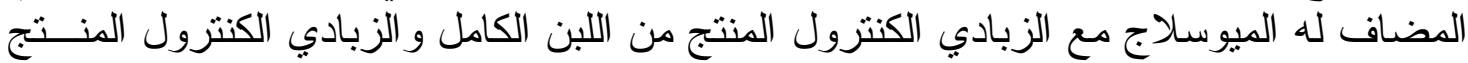

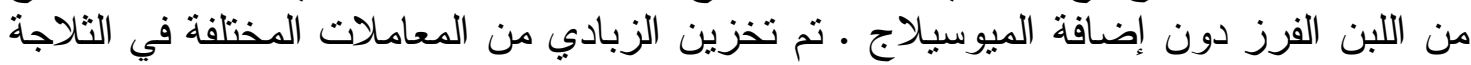

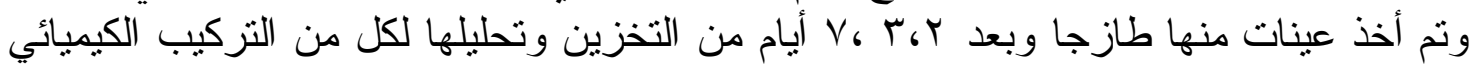

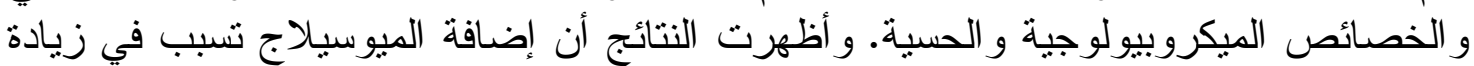

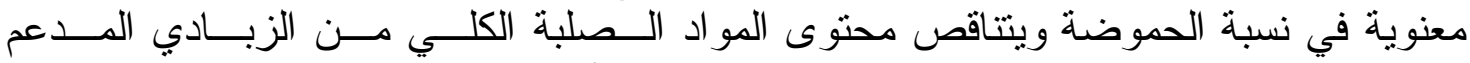

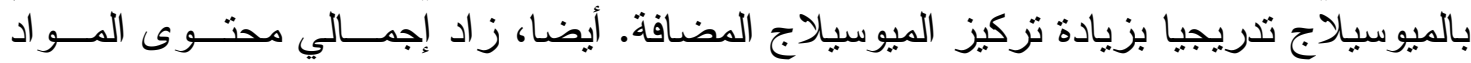

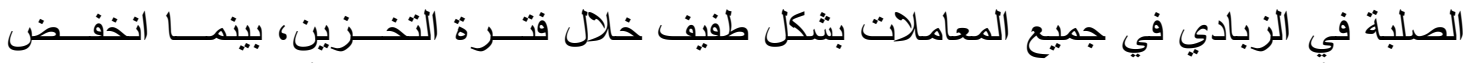

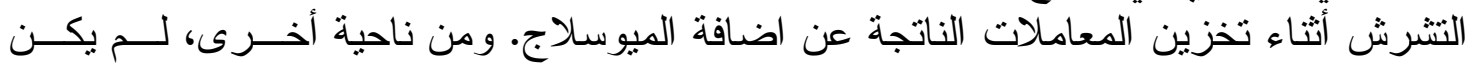

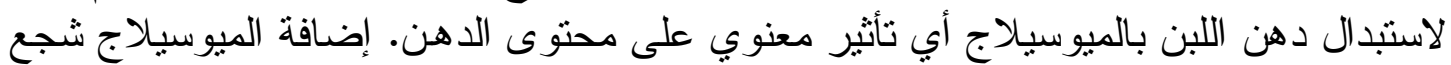

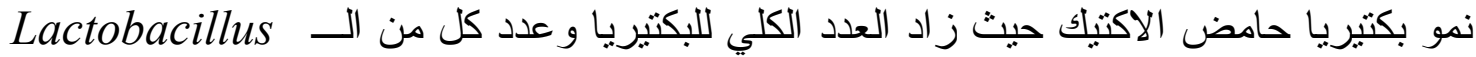
delbrueckii ssp. bulgaricus and Streptococcus thermophilus

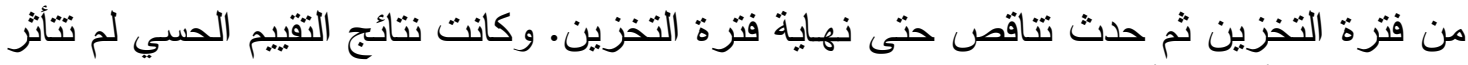

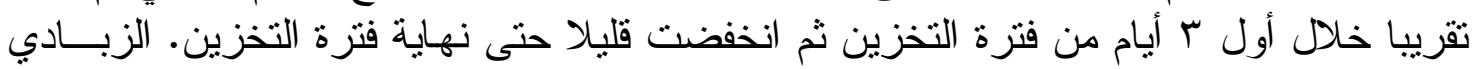

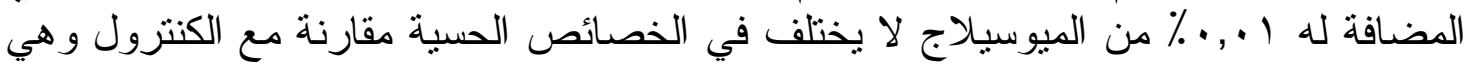

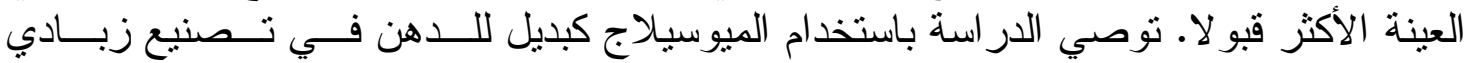

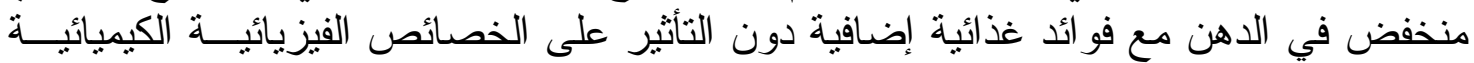

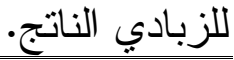

